\title{
Influence of social stress on value of minimal anesthetic concentration of isuflurano in guan (Penelope obscura) captured in wildlife ${ }^{1}$
}

\author{
Bruno Lunardeli ${ }^{2 *}$ (D), Aury N. Moraes ${ }^{3}$, Eloisa C. Bach ${ }^{3}$, Cristiana C. Kuci ${ }^{3}$, \\ Átila Costa ${ }^{4}$, Adson Costa $^{3}$, Maria H.M. Baldini ${ }^{3}$ and Marzia Antonelli ${ }^{3}$
}

\begin{abstract}
Lunardeli B., Moraes A.N., Bach E.C., Kuci C.C., Costa A., Costa A., Baldini M.H.M. \& Antonelli M. 2019. Influence of social stress on minimal anesthetic concentration value of isuflurano in guan (Penelope obscura) captured in wildlife. Pesquisa Veterinária Brasileira 39(8):655-662. Universidade do Estado de Santa Catarina, Av. Luiz de Camões 2090, Conta Dinheiro, Lages, SC 88520-000, Brazil. E-mail: brunoo_lunardeli@hotmail.com

This study aimed to determine and evaluate whether there are differences in values of MAC in wildlife captured guan (Penelope obscura) under different conditions of social stress. This study used 27 bird species guan ( . obscura), divided into two groups: animals kept in the same enclosure (Collective Group) and animals kept in individual cages (Individual Group). The research was conducted at the Advanced Research Base of IBAMA, Painel/SC, and at the Clinical Veterinary Hospital of the "Universidade do Estado de Santa Catarina", Lages/SC. The birds were captured using network trap with manual disarmament and transported to the Veterinary Hospital in cages. The animals were fasted for 2 to 6 hours before the procedure; anesthetic induction was performed with isoflurane for instrumentation. The isoflurane CAM was placed in the target value $1.3 \mathrm{v} \%$ in the first animal of each group, and waited 15 minutes for the nociceptive (electric) stimulus, in the value of 50 hertz and $50 \mathrm{~mA}$, held in faradic form ( 3 consecutive simple stimuli, followed by 2 continuous stimuli). The stimulus was performed on the lateral side of the left pelvic limb in the tibiotarsal region, and the electrodes were fixed with a $22 \mathrm{G}$ needle at a distance of $5 \mathrm{~cm}$ between them. The bird's responses to the stimulus were considered positive (wing movements, head or vocalization) or negative (not presented movements of wings, head or vocalization) and the MAC value of the animal was recorded. Negative responses reduced next birds' MAC value by about 10\%, and MAC positive responses increased by about $10 \%$. Statistical analysis was done by methods up and down and analyze quantal for MAC and paired t-test for equivalent or t-test for variances not equal variances for the physiological variables. At the end of the experiment, the birds were reintroduced in the same capture area. The MAC value of isoflurane in the Collective Group was $1.4 \mathrm{v} \%$ and the Individual Group $1.9 \mathrm{v} \%$ to $0.903 \mathrm{~atm}$. It is observed that guan ( . obscura) in the Collective Group showed lesser anesthetic resistance to isoflurane than the birds in the Individual Group, showing that some levels of social stress can influence the MAC values of the isoflurane.
\end{abstract}

INDEX TERMS: Social stress, minimal anesthetic concentration, isuflurano, guan, Penelope obscura, life free, MAC, anesthesia, wildlife animals, conservation.

\footnotetext{
${ }^{1}$ Received on October 26, 2018.

Accepted for publication on April 9, 2019.

${ }^{2}$ Departamento de Medicina Veterinária, Universidade Federal do Paraná (UFPR), Rua dos Funcionários 1540, Juveve, Curitiba, PR 80035-050, Brazil. *Corresponding author: brunoo_lunardeli@hotmail.com

${ }^{3}$ Departamento de Medicina Veterinária, Universidade do Estado de Santa Catarina (UDESC), Av. Luiz de Camões 2090, Conta Dinheiro, Lages, SC 88520-000, Brazil.

${ }^{4}$ Departamento de Medicina Veterinária, Centro Universitário Unifacvest, Av. Marechal Floriano 947, Centro, Lages, SC 88501-103.
}

RESUMO.- [Influência do estresse social sobre o valor da concentração anestésica mínima de isuflurano em jacus (Penelope obscura) capturados em vida livre.] Este estudo teve como objetivo determinar e avaliar se há diferença nos valores de CAM em jacus (Penelope obscura) capturados em vida livre e submetidos a diferentes condições de estresse social. Foram utilizadas 27 aves da espécie jacu (P. obscura) de vida livre, que depois de capturados foram alocados em dois grupos: 10 animais que permaneceram em grupo no mesmo 
recinto (Grupo Coletivo) e 17 animais que permaneceram em gaiolas individuais (Grupo Individual). A pesquisa foi realizada na Base de Pesquisa Avançada do IBAMA, Painel/SC, e no Hospital de Clínica Veterinária da Universidade do Estado de Santa Catarina, Lages/SC. A captura foi realizada utilizando armadilha de rede com desarmamento manual e as aves foram transportadas para o Hospital Veterinário em gaiolas. Os animais foram submetidos a um jejum alimentar de 2 a 6 horas antes do procedimento, a indução anestésica foi realizada com isoflurano para instrumentação. A CAM de isoflurano foi colocada no valor alvo $1,3 \mathrm{v} \%$ no primeiro animal de cada grupo, e esperado 15 minutos para realização do estímulo nociceptivo (elétrico), no valor de 50 hertz e $50 \mathrm{~mA}$, realizado de forma farádica (3 estímulos simples consecutivos, seguidos de 2 estímulos contínuos). 0 estímulo foi realizado na face lateral do membro pélvico esquerdo na região tibiotársica, e os eletrodos fixados com agulha $22 \mathrm{G}$ a uma distância de $5 \mathrm{~cm}$ entre elas. A resposta da ave ao estímulo foi considerada positiva (movimentos de asas, cabeça ou vocalização) ou negativa (não apresentou movimentos de asas, cabeça ou vocalização) e o valor de CAM do animal foi registrado. Para resultados negativos, a CAM da próxima ave foi reduzida em torno de $10 \%$, para positivos a CAM foi aumentada em torno de 10\%. A análise estatística foi feita pelos métodos up and down e análise quantal para a CAM e teste $t$ de pareado para variâncias equivalentes ou teste t para variâncias não equivalentes para as variáveis fisiológicas. Ao final do experimento as aves utilizadas foram reintroduzidas na mesma área de captura. 0 valor da CAM de isoflurano no Grupo Coletivo foi de $1,4 \mathrm{v} \%$ e no Grupo Individual a CAM de 1,9v\% a 0,903atm, sendo o valor do Grupo Coletivo significativamente menor que o Grupo Individual. Observa-se assim que os jacus ( $P$. obscura) que permaneceram em recinto coletivo apresentaram uma menor resistência anestésica ao isoflurano que as aves que permaneceram em recintos individuais, mostrando que alguns níveis de estresse social como os observados aqui podem influenciar sobre os valores da CAM do isoflurano.

TERMOS DE INDEXAÇÃO: Estresse social, concentração anestésica mínima, isuflurano, jacu, Penelope obscura, vida livre, CAM, anestesia, animais silvestres, conservação.

\section{INTRODUCTION}

Guan (Penelope obscura Temminck, 1815) belongs to the Galliform order, which includes 62 genera and 215 species and its representatives are known as fowl having cosmopolitan distribution (except Antarctica). It is divided into five families: Cracidae, Megapodiidae, Phasianidae, Numinidae, and Odontophoridae (Marques 2014). The Cracidae family will be addressed in this study.

Generally, in the capture and anesthesia of free-living animals, the biological materials collection (blood) for laboratory analysis and a pre-anesthetic physical evaluation is not possible. Patients' physical condition is not correctly assessed, and animals are usually assumed to be healthy (Caulkett \& Arnemo 2015). Given the challenges found during wildlife animal capture, their morbidity and mortality can be high and harmful for the people involved in the capture process. The most common problem is the weather condition, which dictates whether capture is possible or not (Caulkett \& Arnemo 2015).
The anatomy and physiology of birds have some considerable differences, such as their respiratory system, which is composed of two separate and distinct functional components: a ventilation component (airways, air sacs, pneumatic skeleton, and breathing muscles), and gas exchange (pulmonary parabronchi) (Ludders \& Matthews 2007). Airflow through the lungs is unidirectional unlike mammalian "in and out" (Scheid \& Piiper 1972). Birds have central carbon dioxide (PCO2) sensitive central chemoreceptors, and many peripheral chemoreceptors similar to mammalians (Gleeson 1989). For bird anesthesia, it is important to obtain information on the respiratory and cardiovascular systems, as they tend to be sources of frequent problems in the design and implementation of anesthetic protocols for them (Ludders 2015a, 2015b).

The term "minimal alveolar concentration" (MAC) is not appropriate for discussions about inhaled anesthesia in birds because it presupposes the absence of an alveolar lung. Therefore, MAC in birds has been defined as the minimum anesthetic concentration to avoid intentional and crude movement in a bird subjected to painful stimuli (Ludders et al. 1989). Isoflurane is considered the most volatile anesthetic for use in poultry, but sevoflurane may be used because of its faster induction and recovery characteristics (Granone et al. 2012).

Electrical stimulation was first described by Eger 2 nd et al. (1965) to determine the MAC. Currently, electrical stimulation has been used more frequently, varying its intensity in $50 \mathrm{~Hz}$, 50mA and 10ms (Costa 2009, Escobar 2010, Pavez et al. 2011). It is considered a nociceptive stimulus of higher intensity (supramaximal) than the clamping method as demonstrated by Costa (2009), who compared the two stimuli in chickens and observed that in the digital clamping method, the isoflurane MAC was $1.11 \mathrm{v} \%$. With electrical stimulation with hypodermic needles, MAC was $1.47 \mathrm{v} \%$, and repeated mechanical stimuli at the same site may lead to hyperalgesia (Hellebrekers 2002, Hellyer et al. 2002).

The aim of this study was to determine the MAC value of isoflurane in free-living captured guans (Penelope obscura) and to assess whether there is a difference in MAC values in individuals of this species subjected to two different situations of social stress, housed individually or in groups.

\section{MATERIALS AND METHODS}

This study was analyzed and approved by the Animal Experimentation Ethics Committee of the Center for Agricultural Sciences of "Universidade do Estado de Santa Catarina" (CETEA-CAV-UDESC), protocol number 04/2013, and by the Chico Mendes Institute for Biodiversity Conservation (ICMBio), through the Biodiversity Authorization and Information System (SISBIO), protocol number 38776-1. Part of the project was carried out at IBAMA's Advanced Research Base in Panel, Santa Catarina state, and at the Veterinary Clinics Hospital (HCV-CAV-UDESC) in the city of Lages, Santa Catarina state.

Animals. The animals were captured in the IBAMA Advanced Research Base, after a period of conditioning of the birds using cornmeal for two months. The day before the experiment they were transported to the HCV in cages, where the animals were evaluated through biological material collection (blood, feathers, and feces) and physical examination (heart rate, respiratory rate, temperature, weight, level of hydration) to confirm their health.

A total of 27 birds were captured with the aid of a handcrafted $12 \mathrm{~mm}$ mesh trap and manual disarming and divided into two groups. 
The captures were taken in the twilight period, when the birds are most active and used to receiving cornmeal.

Collective Group. It was performed in the first phase of the study. In this group, 10 birds were used. They were captured and left in a group in the same enclosure of dimensions $2 \times 3 \times 3$ meters (width $\times$ length $\times$ height) at IBAMA Advanced Research Base during one day and transported individually to the CAV-UDESC Veterinary Clinic Hospital, where they were placed in a group again in a room of the same size and isolated by a visual barrier.

Individual Group. It was performed in the second phase of the study. There were 17 birds used in this group. After capture, each of them was accommodated in a cage of $0.7 \times 1 \times 0.5$ meters (width $\times$ length $\times$ height) with a visual barrier, not allowing them to see other birds and the environment. They remained there until the time of the experiment, which ranged from 24 to 48 hours.

The feathers taken from the birds were used for ectoparasite research and for sex evaluation. The sexing was performed by polymerase chain reaction (PCR) of the feather samples with the cannons and epithelial tissue for the presence of nucleated cells, and sent to a private laboratory (São Camilo Laboratory, Maringá, Paraná state).

Blood samples were collected under physical restraint by the puncture of the right jugular vein, right or left brachial vein. Approximately $3 \mathrm{ml}$ of blood from each animal were collected, stored in heparin tubes and 3\% EDTA tubes, for hematimetric analyzes (erythrogram, leukogram, thrombocyte count and total plasma protein).

Stool samples were collected at the bottom of the enclosures and sent for co-parasitological exams at the institution's parasitology laboratory.

All birds were held captive for a total period of 3 to 4 days in both groups. The experiment period was from June 7, 2014 to August 8, 2014. The experiment was always performed on weekends, when the presence of people at HCV was low. The period was chosen because it was outside the breeding season of the birds and without dependent parent chicks.

Unhealthy birds had pre-experiment physical and laboratory examination (blood count) values outside the reference values and were excluded from the study.

Experimental design. The animals went through fasting that ranged from 2 to 6 hours. This variation in fasting time occurred because the food was taken from the animals at the same time, but they were randomly selected for the procedure, so the first animals had a shorter fasting time than the last birds. After evaluating the pre-anesthetic parameters of animals under physical restraint (heart rate - HR, respiratory rate $-f$, temperature in degrees celsius - ToC, degree of hydration), the anesthesia was induced with the aid of a calibrated vaporizer ${ }^{1}$ for isoflurane and neonatal mask adapted to a latex glove to prevent leakage, with isoflurane ${ }^{2}$ initially at $2 \mathrm{v} \%$ and increasing $1 \mathrm{v} \%$ per minute to $4 \mathrm{v} \%$, and solubilized at $100 \mathrm{v} \%$ oxygen at a flow rate of $3 \mathrm{~L} \mathrm{~min}^{-1}$. After the loss of ocular and laryngotracheal reflexes was detected, the bird was intubated with a slightly inflated Pean Murphy 3.0 endotracheal tube cuff.

Anesthesia was maintained through an open circuit without gas rebreathing. A gas analyzer ${ }^{3}$ was used to determine end-expiratory isoflurane concentration (EtISO) and end-expiratory carbon dioxide concentration (EtCO2), and assisted ventilation was performed on

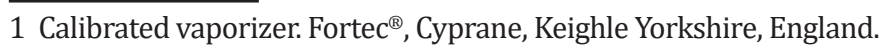

2 Isoflurane. Isoflurine ${ }^{\circledR}$ Cristália, São Paulo, Brazil.

3 Gas analyzer. Poet ${ }^{\circledR}$ IQ2, Criticare, USA. birds with $\mathrm{EtCO}_{2}$ values below 35 or above 45, with an average of 6 to 10 movements per minute, aiming to keep the birds in normocapnia.

After induction, the isoflurane concentration was reduced to $2.5 \mathrm{v} \%$ for poultry instrumentation (pacing needle for stimulation, vascular Doppler ${ }^{4}$, blood pressure cuff ${ }^{5}$, multiparameter monitor pulse oximeter ${ }^{6}$ placed on the barb). Then, it was reduced to isoflurane target MAC, which in the first animal of each group was $1.3 \mathrm{v} \%$.

After the instrumentation, there was a waiting period of 15 minutes to obtain the balance between parabronchial concentration, blood and cerebral circulation of the anesthetic. At this moment (M0), the following parameters were noted: systolic blood pressure (SBP), HR, $\mathrm{f}, \mathrm{T}{ }^{\circ} \mathrm{C}$, arterial blood bicarbonate ion concentration $\left(\mathrm{HCO}^{-3}\right)$, arterial blood oxygen pressure $\left(\mathrm{PaO}_{2}\right)$, carbon dioxide pressure in arterial blood $\left(\mathrm{PaCO}_{2}\right), \mathrm{EtCO}_{2}$ and EtISO, to perform nociceptive stimulation. After the last stimulus or movement of the bird, the parameters at M1 were reevaluated: SBP, $\mathrm{HR}, \mathrm{f}, \mathrm{T}^{\circ} \mathrm{C}, \mathrm{EtCO}_{2}$, EtISO and tabulated.

The nociceptive stimulus used was the electrical stimulus. It was performed using a neurostimulator ${ }^{7}$ in the pharydic mode, being three simple stimuli with a 5 -second interval followed by two 5-second long and 5-second long stimuli. Its intensity was $50 \mathrm{~mA}, 50 \mathrm{hertz}$, and it was performed on the lateral face of the leg (tibiotarsus), with $25 \times 0.7 \mathrm{~mm}$ hypodermic needles transfixed on the skin, at the level of the fibular and superficial fibular nerve, at a distance of $5 \mathrm{~cm}$ from each other.

The answer to the stimulus was considered positive or negative. The negative answer was considered when there was no head lift, wing flap or vocalization, and a positive answer was considered when one of the described events occurred. If not, the isoflurane concentration was reduced by about $10 \mathrm{v} \%$ of the initial concentration and the procedure was repeated in the next bird. This procedure was performed until one bird answered to the painful stimulus (positive answer), in which the isoflurane concentration was increased by about $10 \mathrm{v} \%$ in the next bird.

Systolic blood pressure was noninvasively measured by spectral Doppler, manometer and cuff (2.5 or 3). The HR was measured using a Doppler on the medial face of the contralateral pelvic limb stimulated above the tibiotarsicametatarsal joint, at 5-minute periods and at the pre-stimulus moment. The $\mathrm{f}, \mathrm{EtCO}_{2}$ and EtISO were evaluated by the gas analyzer and the $\mathrm{PaO}_{2}, \mathrm{PaCO}_{2}, \mathrm{HCO}^{-3}$ were evaluated by collecting dorsal metatarsal artery arterial blood with a heparinized $1 \mathrm{~mL}$ syringe with sodium heparin ${ }^{8}$ and processed in a blood gas device 9 .

The temperature was measured full time using an esophageal thermometer connected to a multiparametric monitor maintained from $39^{\circ} \mathrm{C}$ to $41.5^{\circ} \mathrm{C}$ using a thermal blanket ${ }^{10}$. The room temperature was kept close to $22^{\circ} \mathrm{C}$ with a room climate control.

At the end of the study, all birds were released at the same place where they were caught.

Statistical analysis. The values of the pre-stimulus and post-stimulus physiological variables were paired and submitted to the paired t-test, and presented as mean \pm standard deviation (SD). The differences between the Collective and Individual Groups were submitted to the

\footnotetext{
4 Spectral Doppler. Doppler Parks Medical Eletronics ${ }^{\circledR}$ 812, Oregon, USA.

5 Cuff. Latex free ${ }^{\circledR}$, Guandong, China.

6 Multiparameter Monitor. Instramed ${ }^{\circledR}$, Porto Alegre/RS, Brazil.

7 Neurostimulator. Medcir MGF II ${ }^{\circledR}$.

8 Sodium heparin. Cristália, São Paulo/SP, Brazil.

9 Hemogasometry device. Cobas B121, Roche, Mannhein, Germany. 10 Thermal blanket. Estec ${ }^{\circledR}$, São Paulo/SP, Brazil.
} 
f test and then paired t-test for samples of the same variance or the paired t-test for samples with different variances. Minimum anesthetic concentration (MAC) was calculated using Dixon's up-and-down technique and quantal analysis (Dixon 1965, Sonner 2002), using a software ${ }^{11}$ for each analysis. A confidence interval of $95 \mathrm{v} \%$ was considered for physiological variables. The confidence interval for MAC was calculated based on the binomial distribution. Associating this with logistic regression, a probability curve of negative response to stimulus in relation to anesthetic concentration (EtISO) can be found. Differences were considered statistically significant when $\mathrm{p}<0.05$. Only animals belonging to crossover events were analyzed.

\section{RESULTS}

The average weight of the birds used in the Collective Group was $1.3+0.35 \mathrm{~kg}$ and the total anesthetic period (induction until stimulation) averaged $72 \pm 15$ minutes. The average weight of the 17 birds used in the Individual Group was $1.35 \pm 0.2 \mathrm{~kg}$ and the total anesthetic period (induction until stimulation) averaged $65 \pm 12$ minutes.

Three birds from the Collective Group and five birds from the Individual Group needed assistance ventilation, the other birds kept $\mathrm{EtCO}_{2}$ values within normal range.

The isoflurane MAC for birds in the Collective Group obtained by the quantal analysis was $1.4 \mathrm{v} \%$ at $0.903 \mathrm{~atm}$. The isoflurane MAC for birds in the Individual Group obtained by the quantal analysis was $1.9 \mathrm{v} \%$ at $0.903 \mathrm{~atm}$, presenting a statistically significant difference between the groups.

In birds of the Collective Group, crossover events (positive answer followed by negative or vice versa) occurred four times (Fig.1), and the same bird was not included in more than one crossover. Eight out of 10 birds were used for quantal analysis and it was possible to obtain the logistic regression curve with less than $5 \mathrm{v} \%$ error ( $\mathrm{p}<0.05$ ) (Fig.2). The individual number 8 was excluded from the study due to the value $\mathrm{PaCO}_{2}$ was above the acceptable limit.

For Individual Group birds, crossover events (positive answer followed by negative or vice versa) occurred five times (Fig.3), and the same bird was not included in more than one crossover. Ten of the 17 birds were used for quantal analysis and it was possible to obtain the logistic regression curve with less than $5 \mathrm{v} \%$ error $(\mathrm{p}<0.05)$ (Fig.4).

From the physiological variables measured before and after nociceptive stimulation ( $\mathrm{HR}, \mathrm{f}, \mathrm{EtCO}_{2}, \mathrm{SpO}_{2}, \mathrm{~T}^{\circ} \mathrm{C}$ ), a statistical difference was observed only in systolic blood pressure between the birds of the Collective Group and the birds of the Individual Group (Table 1). The birds of the Collective Group had a higher SBP value than the birds of the Individual Group.

Hematimetric evaluations were performed only in the preanesthetic period (Table 2) and pre-stimulus hemogasometric evaluations (Table 3) remained within the reference values for the species.

\section{DISCUSSION}

This bird species was chosen because it is from our region and because it is one of the species that indicates the quality of the environment since it is used to help programs for the management and conservation of protected areas (Strahl \& Grajal 1991). Isoflurane is a safe drug, currently the most

11 Software. Microsoft, Exel ${ }^{\circledR,}$ and SAS ${ }^{\circledR}$.

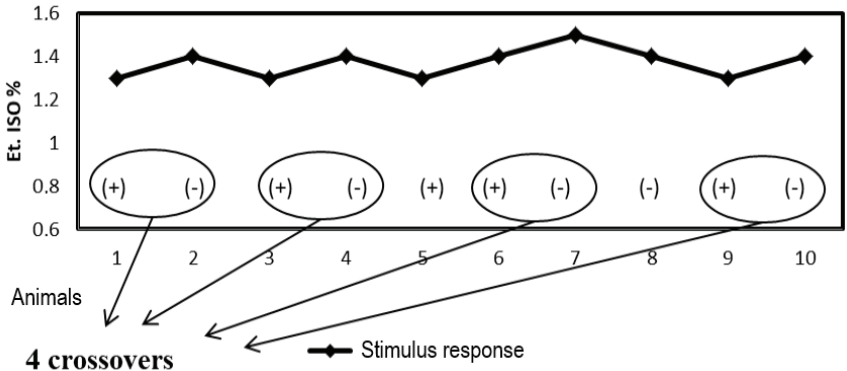

ig.1. The variation of the expired isoflurane concentration (Et.ISO) values observed in each crossover event (circulated), using the up-and-down method in the Collective Group of guans (Penelope obscura).

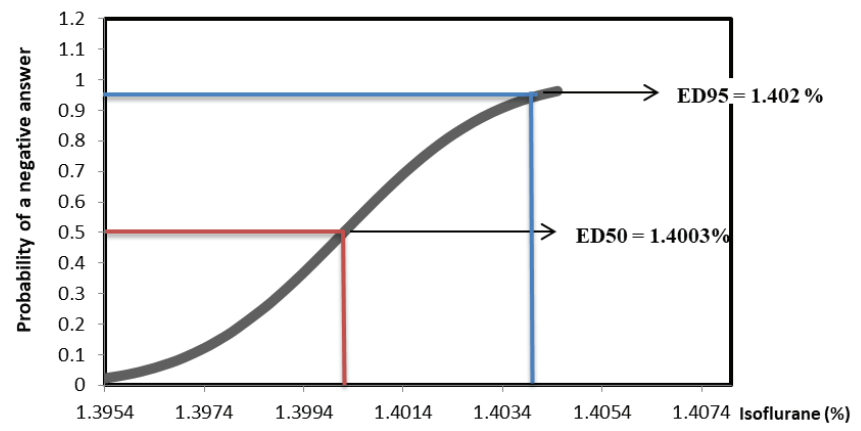

Fig.2. Curve adjusted for determination of the isoflurane minimum anesthetic concentration (MAC) of the Collective Group by the electrical stimulation method with hypodermic needles in the guans (Penelope obscura), which demonstrates the probability of the animal presenting a negative answer to the stimulus in the increase of MAC, indicating the effective dose for $50 \%$ of the population and MAC for $95 \%$ of the population.

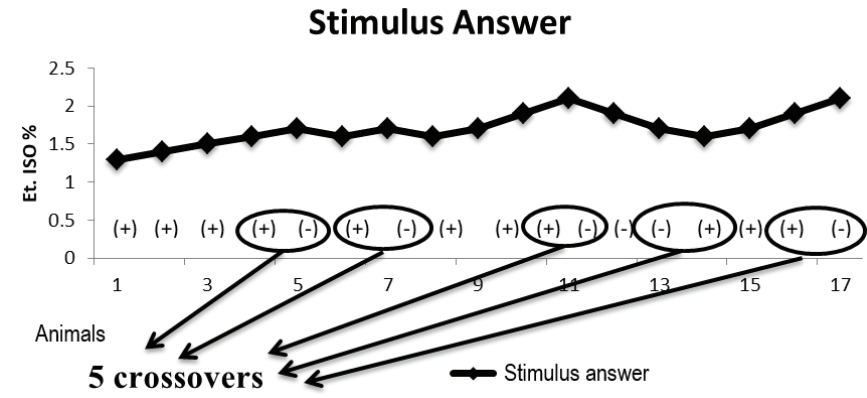

Fig.3. The variation of isoflurane expired concentration (Et.ISO) values observed in each crossover event (circulated), using the up-and-down method in the Individual Group of guans (Penelope obscura).

widely used in human and veterinary medicine, being the most suitable for critically ill patients and for having the best cost-benefit (Oliveira et al. 2014) and currently the most suitable for use in poultry (Granone et al. 2012).

There are several methods described for capturing small and medium-sized birds. In this study, the manual disarming trap method was opted due to the practice and training of the equipment handler. As observed in most capture programs, 


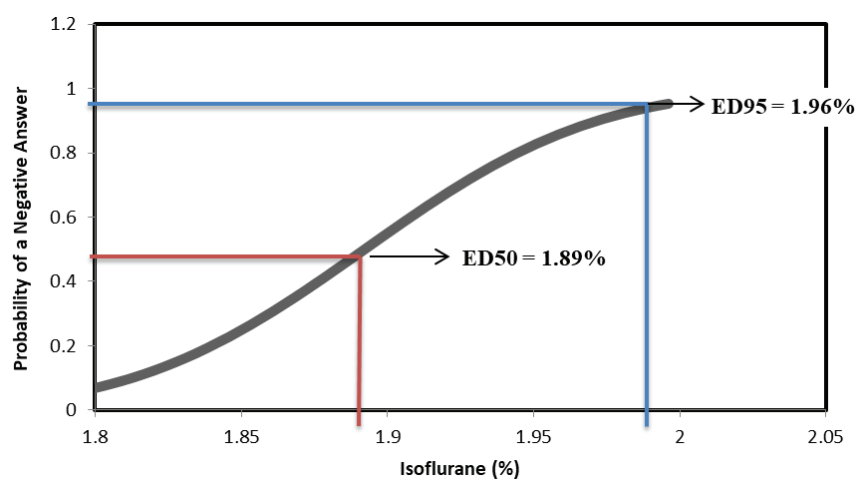

Fig.4. Adjusted curve for determination of the minimum anesthetic concentration (MAC) of Individual Group isoflurane by the electrical stimulation method with hypodermic needles in the guans (Penelope obscura), which demonstrates the probability of the animal presenting a negative response to the stimulus in the increase of MAC, indicating the effective dose for $50 \%$ of the population and MAC for $95 \%$ of the population. their success is a result of the efforts of seasoned professionals and methods studied and tested before starting any new projects (Schemnitz et al. 2009).

In this study, the sex of the birds was not considered for the determination of MAC. Since the birds were randomly captured and sexing was performed in the post-experiment period, it was not possible to perform groups with a specific sex. As quoted by Fantoni et al. (2002), normally the MAC does not vary in animals of the same species, not suffering major interferences due to sex.

It took 10 birds to obtain the MAC in the Collective Group while 17 birds were used for the Individual Group. This difference is because the minimum acceptable number for MAC determination is four crossovers using the up and down method and each bird cannot be present in more than one of these events. Animals that did not participate in crossover events did not enter the analyses. Consequently, the total number always ends up differing from the actual number (Dixon 1965, Mercado et al. 2008). In this case, there was

Table 1. Values of physiological variables presented as mean (+ standard deviation), heart rate beats per minute $\left(\mathrm{HR}_{\mathrm{btm}}{ }^{-1}\right)$, respiratory rate (f), systolic blood pressure ( $\mathrm{SBP}$ - $\mathrm{mmHg}$ ), carbon dioxide concentration at end-expiratory (EtCO ${ }_{2}-\mathrm{mmHg}$ ), partial oxygen saturation in arterial blood $\left(\mathrm{SpO}_{2}\right)$ and central temperature in Celcius degrees ( $\left.{ }^{\circ} \mathrm{C}\right)$, before and after electrical stimulation, in determining the minimum anesthetic concentration (CAM) of guans (Penelope obscura) in the Collective and Individual Groups

\begin{tabular}{|c|c|c|c|c|}
\hline \multirow{4}{*}{ Physiological variables } & \multicolumn{4}{|c|}{ Groups } \\
\hline & \multicolumn{2}{|c|}{ Collective } & \multicolumn{2}{|c|}{ Individual } \\
\hline & Pre & Post & Pre & Post \\
\hline & Mean \pm SD & Mean \pm SD & Mean \pm SD & Mean \pm SD \\
\hline FC beat $/ \min$ & $176+48$ & $187+49$ & $188+52$ & $210+59$ \\
\hline$f \mathrm{mov} / \mathrm{min}$ & $7+2$ & $9+2$ & $7+3$ & $9+2$ \\
\hline BPS mmHg & $131+24^{\mathrm{a}}$ & $130+20^{\mathrm{a}}$ & $109+20^{a}$ & $108+19^{a}$ \\
\hline $\mathrm{EtCO}_{2} \mathrm{mmHg}$ & $42+11$ & $38+14$ & $41+11$ & $39+15$ \\
\hline $\mathrm{SpO}_{2 \%}$ & $98+1$ & $98+1$ & $99+1$ & $99+1$ \\
\hline $\mathrm{T}^{\circ} \mathrm{C}$ & $39,8+0,6$ & $39,8+0,6$ & $40,2+0,5$ & $40,1+0,5$ \\
\hline
\end{tabular}

$\overline{\text { a The difference of SBP after }}$ paired t-test between two groups assuming equivalent variables.

Table 2. Presentation of values (mean + standard deviation) of blood counts (erythrocytes, hemoglobin, hematocrit (g dL $\mathrm{L}^{-1}$ ), mean globular volume (MGV), mean globular hemoglobin concentration (MGHC - \%), thrombocytes, total plasma protein, total leukocytes, heterophile, lymphocytes, eosinophils, basophils, and monocytes) collected in the pre-anesthetic period, from guans (Penelope obscura) in the Collective and Individual Groups

\begin{tabular}{ccc}
\hline & & Groups \\
\cline { 2 - 3 } \cline { 2 - 3 } Blood count & Collective & Individual \\
\cline { 2 - 3 } & $2,35+0,4 \times 10^{6} / \mu \mathrm{L}$ & Mean $\pm \mathrm{SD}$ \\
\hline Erythrocytes & $9,37+0,99 \mathrm{~g} / \mathrm{dL}$ & $11+2 \mathrm{~g} / \mathrm{dL}$ \\
Hemoglobin & $36+3 \%$ & $41+5 \%$ \\
Hematocrit & $161,55+40,43 \mathrm{fL}$ & $161+14,59 \mathrm{fL}$ \\
MGV & $25,5+1,4 \%$ & $27+3,1 \%$ \\
MGHC & $14500+5032 / \mu \mathrm{L}$ & $13771+5499 / \mu \mathrm{L}$ \\
Thrombocytes & $3,91+0,22 \mathrm{~g} / \mathrm{dL}$ & $3,6+0,4 \mathrm{~g} / \mathrm{dL}$ \\
Plasma Protein & $12121+4954 / \mu \mathrm{L}$ & $9224+4997 / \mu \mathrm{L}$ \\
Leukocytes & $7465+3796 / \mu \mathrm{L}$ & $5354+2997 / \mu \mathrm{L}$ \\
Heterophiles & $2566+1587 / \mu \mathrm{L}$ & $2293+1642 / \mu \mathrm{L}$ \\
Lymphocytes & $524+318 / \mu \mathrm{L}$ & $174+181 / \mu \mathrm{L}$ \\
Eosinophils & $125+139 / \mu \mathrm{L}$ & $202+166 / \mu \mathrm{L}$
\end{tabular}


Table 3. Presentation of values (mean + standard deviation) of blood gas ( $\mathrm{pH})$, arterial oxygen partial pressure $\left(\mathrm{PaO}_{2}-\mathrm{mmHg}\right)$, arterial carbon dioxide partial pressure $\left(\mathrm{PaCO}_{2}-\mathrm{mmHg}^{-1}\right)$ and bicarbonate $\left(\mathrm{HCO}_{-3}-\mathrm{mmol} \mathrm{L}^{-1}\right)$ performed at the time of electrical stimulation during the determination of the minimum anesthetic concentration (MAC) of the Collective and Individual Groups

\begin{tabular}{cccc}
\hline & & Groups & \\
\cline { 2 - 3 } Hemogasometry & Collective & Individual \\
\cline { 2 - 3 } & $\mathrm{pH}$ & $7.4+0.04$ & Mean \pm SD \\
\hline $\mathrm{PaO}_{2}$ & $137+72$ & $7.4+0.04$ \\
$\mathrm{PaCO}_{2}$ & $42.1+5.4$ & $185+46$ \\
$\mathrm{HCO}^{-3}$ & $29+3.26$ & $43.4+7.3$ \\
& & $28.2+3.8$
\end{tabular}

a total of 10 birds and an effective number of eight birds in the Collective Group, obtaining four crossovers. In the birds of the Individual Group, there were 17 birds and an effective number of 10 birds, obtaining five crossovers, being possible in both groups to perform the quantal analysis and formation of the logistic regression curve.

Positive stimulus was considered, that is, with one or more of the following responses: vocalization, flapping, sudden movement of the contralateral to stimulated limb, head and tail raising (Nicolau et al. 2002, Mercado et al. 2008, Escobar 2010, Kim et al.2011, Pavez et al.2011, Chan et al.2013). This was well determined and standardized in this study because the lack of this standardization is a major cause of MAC value variability (Oliveira et al. 2014).

The initial MAC value for baseline was determined at $1.3 \mathrm{v} \%$ isoflurane in both groups, which was obtained from a pilot study conducted earlier. The pilot study was very important because no reference was found for this species in the literature for isoflurane MAC values or the description of anesthetic techniques. Only Costa (2009) citation using chickens (Gallus gallus domesticus) with electrical stimulation obtained the MAC value of $1.47 \mathrm{v} \%$.

A 15 min period for the drug to stabilize between lung, blood, and brain was established. This time was based on the main studies that performed MAC determination in birds (Ludders et al. 1989, Mercado et al. 2008, Costa 2009, Escobar 2010, Kim et al. 2011, Chan et al. 2013).

Body temperature is one of the most important physiological variables to be controlled, as decreasing body temperature reduces animal metabolism and thereby decreases anesthetic consumption; increasing body temperature elevates animal enzymatic metabolism, increasing anesthetic consumption (Quasha et al. 1980).

The temperature of the birds in the research was maintained from 39.2 to $40.5^{\circ} \mathrm{C}$, a value considered basal for birds of this order and observed as ideal in most studies (Costa 2009, Escobar 2010, Kim et al. 2011, Pavez et al. 2011). Nicomedus et al. (1969) and Ludders et al. (1989) state that to be considered MAC, besides the control of some physiological parameters such as body temperature, it is necessary to perform a logistic probability analysis, which in this study was performed by quantal analysis.

The quantal analysis is based on data obtained by the up-and-down method, unlike the bracketing study design method, which is one of the most widely used in animals (Sonner 2002). Although it is the most suitable method for animals in general, it was not chosen due to the long anesthetic time and because it is not considered a logistic probability analysis, as mentioned by Ludders et al. (1989) and Sonner (2002). Furthermore, in this method individual MAC is obtained and then performed for the group (Hellebrekers 2002, Hellyer et al. 2002), so we wanted to avoid possible hyperalgesia caused by repeated nociceptive stimuli at the same site since. In human and dog studies no differences were observed in the value of MAC obtained from the Bracketing study design and the up-and-down method (Sonner 2002).

The physiological parameters $\left(\mathrm{HR}, \mathrm{f}, \mathrm{T}^{\circ} \mathrm{C}, \mathrm{PAS}, \mathrm{SpO}_{2}, \mathrm{EtCO}_{2}\right)$, blood gas values ( $\mathrm{pH}, \mathrm{PO} 2, \mathrm{PCO} 2$ and $\mathrm{HCO}_{-3}$ ) measured in birds during the experiment and hematological values are within the values observed in other studies with Galliformes (Naganobu \& Hagio 2000, Costa 2009, Escobar 2010).

The isoflurane MAC in healthy adult guans (Penelope obscura) determined by the up-and-down method was $1.4 \mathrm{v} \%$ for the Collective Group and $1.9 \mathrm{v} \%$ for the birds of the Individual Group. In this study, electrical stimulation was chosen as a supramaximal nociceptive stimulus, as this type of stimulation has been evaluated as superior to other methods, even in birds described by other authors (Costa 2009, Escobar 2010, Pavez et al. 2011). Electrical stimulation has shown a higher standardization and more accurate techniques, as observed in all studies cited, such as the same frequency, voltage and time $(50 \mathrm{~Hz}, 50 \mathrm{~mA}$, and $10 \mathrm{~ms})$ and location (tibiotarsal lateral face). This is not observed in the digital or interdigital clamping methods, as there is no standardization of the clamping location, type of clamping and the amount of pressure applied at the point. It is only known that it is done at the level of the clamping rack, and in the other points the authors made their own adaptations (Ludders et al. 1988, 1989, Naganobu \& Hagio 2000, Nicolau et al. 2002, Mercado et al. 2008, Kim et al. 2011, Chan et al. 2013, Oliveira et al. 2014).

The MAC value for the Collective Group was lower than the Individual Group, but its value of $1.4 \mathrm{v} \%$ resembles the MAC value for birds of the same order, being $1.47+0.10 \mathrm{v} \%$ in chickens (Gallus gallus) (Costa 2009). The MAC value of $1.9 \mathrm{v} \%$ for the Individual Group is similar to the birds of Pavez et al. (2011), where the MAC of isoflurane in red-tailed buttocks (Buteo jamaicensis) was $2.05 \pm 0.45 \mathrm{v} \%$.

Blood collection for blood gas analysis was recommended only before the stimulus to confirm that $\mathrm{PaCO}_{2}$ was not outside the expected values, so as not to influence the MAC value. As quoted by Brosnan et al. (2007), in which the increase in $\mathrm{PaCO}_{2}$ may lead to a decrease in the final MAC value, a small increase in the $\mathrm{PaCO}_{2}$ value of the birds of the Individual Group was observed. The birds of the Collective Group remained in 
normocapnia, and the difference in MAC value between the two groups should not be attributed to this factor. This slight increase in $\mathrm{PaCO}_{2}$ in the Individual Group may be justified because it has been suggested that responses to systemic stressors associated with immediate survival, such as hypoxia and hypercapnia, are likely to be directly transmitted from brain stem nuclei and are not associated with higher-order CNS processing and conscious experiences (Herman \& Cullinan 1997). These factors can be considered stress determinant.

Spontaneous ventilation was used in this study, and the animal was ventilated only when $\mathrm{PaCO}_{2}$ and $\mathrm{EtCO}_{2}$ did not have normocapnia values in the pre-stimulation analyses (Nicolau et al. 2002, Mercado et al. 2008, Costa 2009, Chan et al. 2013). Unlike, other authors who opted for controlled ventilation with or without gas re-inhalation system (Escobar 2010, Kim et al. 2011). Chan et al. (2013) stated that spontaneous ventilation becomes more reliable without a gas rebreathing system because air does not go through a $\mathrm{CO}_{2}$ filtration system and reuse of the anesthetic agent. Not knowing whether mild hypercapnia can alter MAC in guans (Penelope obscura), it was decided to keep $\mathrm{PaCO}_{2}$ and $\mathrm{EtCO}_{2}$ levels within normal limits because in some studies involving birds with resulting relative hypoventilation, known to decrease the requirement for inhalant agents to varying levels observed in different species, changing the final MAC value to less than it should be (Brosnan et al. 2007). In rats, the increase in end-tidal $\mathrm{CO}_{2}$ concentration at MAC of halothane, isoflurane, and desflurane decreased dose-dependent (Brosnan et al. 2007). Chemonges (2014) observed that intermittent pressure ventilation in cockatoos (Cacatua) leads to an increase in isoflurane-dependent dose anesthetic depth.

Within the evaluated parameters, a statistical difference was observed only in systolic blood pressure between the birds of the Collective Group and the Individual Group, in which the SBP value was $131 \pm 24 \mathrm{mmHg}$ in the Collective Group and $109 \pm 20 \mathrm{mmHg}$ in the Individual Group. This difference between the two groups may be explained by the fact that MAC in the birds of the Individual Group was significantly higher (1.35 times higher), so a higher dose of inhaled isoflurane is required, leading to mild hypotension. This side effect was observed in studies in which after MAC determination, the isoflurane dose was increased by 1.5 and 2 times to assess its cardiovascular effect. In this case, only the dose-dependent decrease in blood pressure was observed, with no change in heart rate (Ludders et al. 1989, Naganobu \& Hagio 2000, Kim et al. 2011). The same result was observed in this study.

In the determination of the isoflurane MAC, a statistical difference was observed between the birds of the Collective Group and those of the Individual Group, with the highest MAC value observed in the Individual Group. One of the causes of this difference can be the stress intensified by the separation of individuals (social stress), which alters the natural behavior of the species, considering that these birds have a habit of staying in groups in the wild (Marques 2014). The influence of social behavior on pain and stress levels was also described by Gentle \& Tilston (1999), who observed that chickens that remained in the group after application of sodium urate in the left ankle had a higher pain threshold than birds that remained isolated in the enclosure, attributing this behavioral change to social stress. Massone (2011) mentioned that accommodations in the pre-anesthetic period are very important, as they interfere with animal behavior and it is known that the environment (boxes, stalls, kennels, and stables) where animals stay before surgical interventions may cause a high level of stress to the point of being affected to the anesthetic act. According to Sharp et al. (2006), simply placing mice in an unknown exposure chamber containing ambient air produces excitement lead to distress. This may justify the higher stress in the birds of the Individual Group because, in addition to being removed from their natural environment, they were allocated so they did not observe the other individuals and the rest of the environment.

The Individual Group was considered the one with the greatest influence of social stress because it had a higher MAC value. What characterize the influence of stress are the increase of blood glucose, lactate free fatty acids, and the increase of metabolism rates, oxygen uptake, and accelerated pharmacological metabolism (Muir 2007).

In birds, the anesthetic potency of an inhaled drug is determined by its minimum anesthetic concentration (MAC), a method similar to the one used for mammals (Ludders et al. 1989). Apparently, this was the first paper reporting the determination of isoflurane MAC in guans (Penelope obscura) and the observation of the influence of social stress on MAC.

\section{CONCLUSIONS}

The isoflurane MAC value for these birds was close to other galiforms, but increased significantly when birds were subjected to stress, such as being kept individually.

Based on the MAC results of this study (Collective Group vs. Individual Group), the ideal acclimatization is fundamental for animals that will undergo clinical, surgical and anesthetic treatments.

This information becomes important for future studies in determining MAC in birds of this species or other species that can be easily influenced if subjected to social conditions outside the habitat, especially for birds that live in groups.

Acknowledgments.- We thank "Universidade do Estado de Santa Catarina" for the opportunity of conducting the research, IBAMA for providing the staff and the capture and storage of animals, to all the people who participated in this research, and for the Santa Catarina Research Support Foundation (FAPESC).

Conflict of interest statement.- The authors have no competing interests.

\section{REFERENCES}

Brosnan R.J., Eger 2nd E., Laster M.J. \& Sonner J.M. 2007. Anesthetic properties of carbon dioxide in the rat. Anesth. Analg. 105(1):103-106. <http:// dx.doi.org/10.1213/01.ane.0000265556.69089.78> <PMid:17578964>

Caulkett N.A. \& Arnemo J.M. 2015. Comparative anesthesia and analgesia of zoo animals and wildlife, p.764-776. In: Grimm K.A., Lamont L.A., Tranquilli W.J., Greene S.A. \& Robertson S.A. (Eds), Lumb and Jones' Veterinary Anesthesia and Analgesia. 5th ed. John Wiley and Sons, Iowa. <http:// dx.doi.org/10.1002/9781119421375.ch40>

Chan F.T., Chang G.R., Wang H.C. \& Hsu T.H. 2013. Anesthesia with isoflurane and sevoflurane in the crested serpent eagle (Spilornis cheela hoya): minimum anesthetic concentration, physiological effects, hematocrit, plasma chemistry and behavioral effects. J. Vet. Med. Sci. 75(12):1591 1600. <http://dx.doi.org/10.1292/jvms.13-0161> <PMid:23955396>

Chemonges S. 2014. Effect of intermittent positive pressure ventilation on depth of anaesthesia during and after isoflurane anaesthesia in sulphur- 
crested cockatoos (Cacatua galerita galerita). Vet. Med. Int. 2014:1-7. <http://dx.doi.org/10.1155/2014/250523> <PMid:24587938>

Costa A. 2009. Pinçamento digital e estímulo elétrico na determinação da concentração anestésica mínima (CAM) de isoflurano em galinhas (Gallus gallus) pré tratadas ou não com Meloxicam. Master's Thesis, Universidade do Estado de Santa Catarina, Florianópolis, SC. 75p.

Dixon W.J. 1965. The up-and-down method for small samples. J. Am. Stat. Assoc. 60(312):967-978. <http://dx.doi.org/10.1080/01621459.1965 $.10480843>$

Eger 2nd E.I., Saidman L.J. \& Brandstater B. 1965. Minimum alveolar anesthetic concentration: a standard of anesthetic potency. Anesthesiology 26(6):756-763. <http://dx.doi.org/10.1097/00000542-19651100000010><PMid:5844267>

Escobar A. 2010. Efeitos do butorfanol na concentração anestésica mínima do sevofluorano em galinha d'angola (Numida meleagris). Doctoral Dissertation, Faculdade de Ciências Agrária e Veterinárias, Universidade Estadual Paulista, Jaboticabal. 85p.

Fantoni D.T., Cortopassi S.R.G. \& Bernardi M.M. 2002. Anestésicos inalatórios, p.132-142. In: Spinosa H.S., Górniak S.L. \& Bernardi M.M. (Eds), Farmacologia Aplicada a Medicina Veterinária. 3a ed. Guanabara Koogan, Rio de Janeiro.

Gentle M.J. \& Tilston V.L. 1999. Reduction in peripheral inflammation by changes in attention. Physiol. Behav. 66(2):289-292. <http://dx.doi. org/10.1016/S0031-9384(98)00297-2><PMid:10336156>

Gleeson M. 1989. Control of breathing, p.439-484. In: King AS \& McLelland J. (Eds), Form and Function in Birds. Academic Press, London.

Granone T.D., Francisco O.N., Killos M.B., Quandt J.E., Mandsager R.E. \& Graham L.F. 2012. Comparison of three different inhalant anesthetic agents (isoflurane, sevoflurane, desflurane) in red-tailed hawks (Buteo jamaicensis). Vet. Anest. Analg. 39(1):29-37.<http://dx.doi.org/10.1111/j.1467-2995.2011.00668. $\mathrm{x}><$ PMid:22103452>

Hellebrekers L.J. 2002. Dor em Animais. Ed. Manole, São Paulo. 166p.

Hellyer P.W., Robertson S.A. \& Fails A.D. 2002 Pain and its management, p.3866. In: Tranquilli J.C., Thurmon J.C. \& Grinn K.A. (Eds), Lumb and Jones' Veterinary Anesthesia and Analgesia. 4th ed. Blackwell Publishing, Iowa.

Herman J.P. \& Cullinan W.E. 1997. Neurocircuitry of stress: central control of the hypothalamo-pituitary-adrenocortical axis. Trends Neurosci. 20(2):78-84. <http://dx.doi.org/10.1016/S0166-2236(96)10069-2><PMid:9023876>

Ludders J.W. 2015a. Respiration in birds, p.245-262. In: Reece W.O., Erickson H.H. Goff J.P. \& Uemura E.E. (Eds), Dukes' Physiology of Domestics Animals. 13th ed. John Wiley and Sons, Iowa.

Ludders J.W. 2015b. Comparative anesthesia and analgesia of birds, p.800818. In: Grimm K.A., Lamont L.A. Tranquilli W.J., Greene S.A. \& Robertson S.A. (Eds), Lumb and Jones' Veterinary Anesthesia and Analgesia. 5th ed. John Wiley and Sons, Iowa.

Ludders J.W. \& Matthews N.S. 2007. Birds, p.923-952. In: Tranquilli J.C., Thurmon J.C. \& Grinn K.A. (Eds), Lumb and Jones' veterinary anesthesia and analgesia. 4th ed. Blackwell Publishing, Iowa.

Ludders J.W., Mitchell G.S. \& Schaefer S.L. 1988. Minimum anesthesic dose and cardiopulmonary response for halotanein chickens. Am. J. Vet. Res. 49(6):929-932. <PMid:3135771>

Ludders J.W., Rode J. \& Mitchell G.S. 1989. Isoflurane anesthesia in sandhill cranes (Grus canadensis): minimal anesthetic concentration and cardiopulmonary dose-response during spontaneous and controlled breathing. Anest. Analg. 68(4):511-516. <http://dx.doi.org/10.1213/00000539-19890400000016><PMid:2929984>
Kim Y.K., Lee S.S., Suh E.H., Lee L., Lee H.C., Lee H.J. \& Yeon S.C. 2011. Minimum anesthetic concentration and cardiovascular dose-response relationship of isoflurane in cinereous vultures (Aegypius monachus). J. Zoo Wild. Med. 42(3):499-503.<http://dx.doi.org/10.1638/2010-0151.1><PMid:22950326>

Marques M.V.R. 2014. Galiformes (aracuã, jacu, jacutinga, mutum e uru), p.354-383. In: Cubas Z.S., Silva J.C. R. \& Catão-Dias J.L. (Eds), Tratado de Animais Selvagens. $2^{\underline{a}}$ ed. Roca, São Paulo.

Massone F. 2011. Considerações gerais, p.1-16. In: Ibid. (Ed.), Anestesiologia Veterinária: farmacologia e técnicas. $6^{\underline{a}}$ ed. Guanabara Koogan, Rio de Janeiro.

Mercado J.A., Larsen S., Wack R.F. \& Pypendop B.H. 2008. Minimum anesthetic concentration of isoflurane in captive thick-billed parrots (Rhynchopsitta pachyrhyncha). Am. J.Vet. Res. 69(2):189-194. <http://dx.doi.org/10.2460/ ajvr.69.2.189><PMid:18241014>

Muir W.W. 2007. Considerations for general anesthesia, p.7-37. In: Tranquilli J.C., Thurmon J.C. \& Grinn K.A. (Eds), Lumb and Jones' Veterinary Anesthesia and Analgesia. 4th ed. Blackwell Publishing, Iowa.

Naganobu K. \& Hagio M. 2000. Doserelated cardiovascular effects of isoflurane in chickens during controlled ventilation. J. Vet. Med. Sci. 62(4):435-437. <http://dx.doi.org/10.1292/jvms.62.435><PMid:10823732>

Nicolau A.A., Fantoni D.T., Auler J.O. \& Ambrósio A. 2002. 0 sevoflurano em psitacídeos (Amazona aestiva) determinação da Dose Anestésica Mínima (DAM) para a produção da anestesia geral. Ciência Rural 32(5):781-786. <http://dx.doi.org/10.1590/S0103-84782002000500007>

Nicomedus H.F., Nassiri-Ralimi C. \& Bachman L. 1969. Median effective doses (ED50) of halotane in adults and children. Anesthesiology 31(4):344-348. <http://dx.doi.org/10.1097/00000542-196910000-00011><PMid:5811601>

Oliveira M.G.C., Moraes A.M.L., Lima A.G.A., Paiva A.L.C., Nunes T.L., Passos Y.D.B., Oliveira M.F. \& Paula V.V. 2014. Determinação da concentração alveolar mínima do isoflurano em catetos (Tayassu tajacu). Pesq. Vet. Bras. 6(34):576-581. <http://dx.doi.org/10.1590/S0100-736X2014000600012>

Pavez J.C., Hawkins M.G., Pascoe P.J., Knych H.K.D. \& Kass P.H. 2011. Effect of fentanyl target-controlled infusions on isoflurane minimum anaesthetic concentration and cardiovascular function in red-tailed hawks (Buteo Jamaicensis). Vet. Anesth. Analg. 38(4):344-351. <http://dx.doi. org/10.1111/j.1467-2995.2011.00627.x><PMid:21672126>

Quasha A.L., Eger 2nd E.I. \& Tinker J.H.1980. Determination and applications of MAC. Anesthesiology 53(4):315-334.<http://dx.doi.org/10.1097/00000542198010000-00008><PMid:6107067>

Sharp J., Azar T. \& Lawson D. 2006. Comparison of carbon dioxide, argon, and nitrogen for inducing unconsciousness or euthanasia of rats. J. Am. Assoc. Lab. Anim. Sci. 45(2):21-25. <PMid:16542038>

Scheid P. \& Piiper J. 1972. Cross current gas exchange in avian lungs: effect of reversed parabronchial air flow in ducks. Respiratory Physiol. 16(3):304-312. <http://dx.doi.org/10.1016/0034-5687(72)90060-6><PMid:4644057>

Schemnitz S.D., Batcheller G.R., Lovallo M.J., White H.B. \& Fall M.W. 2009. Capturing and handling wild animals. Natl Wildl. Res. Center 1:232-269.

Sonner J.M. 2002. Issues in the design and interpretation of minimum alveolar anesthetic concentration (MAC) studies. Anest. Analg. 95(3):609-614. <PMid:12198046>

Strahl S.D. \& Grajal A. 1991. Conservation of large avian fugivores and the management of neotropical protected areas. Oryx 25(1):50-55. <http:// dx.doi.org/10.1017/S0030605300034074> 